\title{
Meningkatkan Kompetensi Penyusunan Rencana Pelaksanaan Pembelajaran Berorientasi Pada Ketrampilan Berpikir Tingkat Tinggi (Higher Order Thingking Melalui Focus Group Discussion (FGD)
}

\author{
Zuleha \\ Dinas Pendidikan Kabupaten Luwu Utara \\ zuleha@gmail.com
}

\begin{abstract}
ABSTRAK
Penelitian Tindakan Sekolah (PTS) ini bertujuan Untuk mendeskripsikan kompetensi guru kelas menyusun rencana pelaksanaan pembelajaran yang berorientasi pada keterampilan berpikir tingkat tinggi Higher Order Thingking Skill (HOTS) dalam pembelajaran tematik di UPT SD Negeri 210 Lemah abang Kabupaten Luwu Utara Tahun Pelajaran 2019/2020. Metode yang digunakan dalam penelitian ini adalah metode Penelitian Tindakan Sekolah (PTS). Subjek penelitian yaitu UPT SD Negeri 210 Lemah abang Kabupaten Luwu Utara Tahun Pelajaran 2019/2020, dengan jumlah guru sebanyak 12 (dua belas) orang. Teknik pengumpulan data yang digunakan adalah teknik observasi, wawancara.Penelitian ini dilakukan 2 siklus yaitu siklus pertama dilakukan $F G D$ dapat meningkatkan kompetensi guru dalam menyusun rencana pelaksanaan pembelajaran berorientasi pada keterampilan berpikir tingkat tinggi HOTS Dalam Pembelajaran Tematik. Guru menunjukkan keseriusan dalam memahami dan melakukan diskusi FGD dengan bimbingan dari peneliti. Informasi ini peneliti peroleh dari hasil pengamatan pada saat bimbingan diskusi FGD meningkatkan kompetensi guru menyusun rencana pelaksanaan pembelajaran berorientasi pada keterampilan berpikir tingkat tinggi HOTS Dalam Pembelajaran Tematik. Kesimpulan akhir dari penelitian ini adalah dengan FGD dapat meningkatkan kompetensi guru dalam menyusun rencana pelaksanaan pembelajaran berorientasi pada keterampilan berpikir tingkat tinggi HOTS Dalam Pembelajaran Tematik. Hal itu dapat dibuktikan dari hasil observasi/pengamatan yang memperlihatkan bahwa terjadi peningkatan kompetensi guru dari siklus ke siklus. yaitu terjadi peningkatan sebesar $16,00 \%$ dari siklus pertama kesiklus kedua.
\end{abstract}

Kata kunci: kompetensi guru, penyusunan RPP, berfikir tingkat tinggi

\section{ABSTRACT}

This School Action Research (PTS) aims to describe the competence of class teachers in compiling learning plans oriented to higher order thinking skills Higher Order Thingking Skills (HOTS) in thematic learning at UPT SD Negeri 210 Weak Abang, North Luwu District 2019/2020 Academic Year. The method used in this study is the School Action Research (PTS) method. The subject of the study was UPT SD Negeri 210 Lemah Abang, North Luwu Regency in the 2019/2020 Academic Year, with a total of 12 (twelve) teachers. The data collection technique used was observation, interview. This research was conducted in 2 cycles, namely the first cycle conducted by the FGD can improve teacher competence in preparing plans for implementing learning oriented to HOTS high-level thinking skills in Thematic Learning. The teacher shows seriousness in understanding and conducting FGD discussions with guidance from researchers. This information was obtained from observers when observing the FGD discussion guidance increasing the competence of teachers in compiling an implementation plan of learning oriented at higher-order thinking skills HOTS in Thematic Learning. The final conclusion of this study is that the FGD can improve teacher competency in developing learning plans oriented to HOTS higher level thinking skills in Thematic Learning. This can be proven from the results of observations / observations which show that an increase in teacher competence from cycle to cycle. namely an increase of $16.00 \%$ from the first cycle to the second cycle.

Keywords: teacher competence, preparation RPP, higher order thingking skills

\section{PENDAHULUAN}

Implementasi Kurikulum 2013 yang menjadi rujukan proses pembelajaran pada satuan pendidikan, sesuai kebijakan, perlu mengintegrasikan Penguatan Pendidikan Karakter (PPK). Integrasi tersebut bukan 
sebagai program tambahan atau sisipan, melainkan sebagai satu kesatuan mendidik dan belajar bagi seluruh pelaku pendidikan di satuan pendidikan. Peraturan Presiden Nomor 87 Tahun 2017 tentang Penguatan Pendidikan Karakter (PPK) menjadikan pendidikan karakter sebagai "Gerakan pendidikan di bawah tanggung jawab satuan pendidikan untuk memperkuat karakter peserta didik melalui harmonisasi olah hati, olah rasa, olah pikir, dan olah raga dengan pelibatan dan kerja sama antara satuan pendidikan, keluarga, dan masyarakat sebagai bagian dari Gerakan Nasional Revolusi Mental (GNRM)" (Pasal 1, ayat 1). Perpres ini menjadi landasan awal untuk kembali meletakkan pendidikan karakter sebagai jiwa utama dalam penyelenggaraan pendidikan di Indonesia, diperkuat dengan dikeluarkannya Permendikbud Nomor 20 Tahun 2018 tentang Penguatan Pendidikan Karakter Pada Satuan Pendidikan Formal. Penguatan Pendidikan Karakter menjadi kebijakan nasional yang harus diimplementasikan pada setiap pelatihan dalam rangka peningkatan kompetensi guru.

Pemerintah mengharapkan para peserta didik mencapai berbagai kompetensi dengan penerapan HOTS atau Keterampilan Bepikir Tingkat Tinggi. Kompetensi tersebut yaitu berpikir kritis (criticial thinking), kreatif dan inovasi (creative and innovative), kemampuan berkomunikasi (communication skill), kemampuan bekerja sama (collaboration) dan kepercayaan diri (confidence). Lima hal yang disampaikan pemerintah yang menjadi target karakter peserta didik itu melekat pada sistem evaluasi kita dalam ujian nasional dan merupakan kecakapan abad 21. Keterampilan Berpikir Tingkat Tinggi (High Order Thinking Skill) juga diterapkan menyusul masih rendahnya peringkat Programme for International Student Assessment (PISA) dan Trends in International Mathematics and Science Study (TIMSS) dibandingkan dengan negara lain, sehingga standar soal ujian nasional dicoba ditingkatkan untuk mengejar ketertinggalan.

Pengembangan pembelajaran berorientasi pada keterampilan berpikir tingkat tinggi atau Higher Order Thinking Skill (HOTS) merupakan program yang dikembangkan sebagai upaya Kementerian Pendidikan dan Kebudayaan melalui Direktorat Jenderal Guru dan Tenaga Kependidikan (Ditjen GTK) dalam upaya peningkatan kualitas pembelajaran dan meningkatkan kualitas lulusan. Program ini dikembangkan mengikuti arah kebijakan Kementerian Pendidikan dan Kebudayaan yang pada tahun 2018 telah terintegrasi Penguatan Pendidikan Karakter dan pembelajaran berorientasi pada Keterampilan Berpikir Tingkat Tinggi atau Higher Order Thinking Skill (HOTS).

Anderson dan Krathwohl (2001) merevisi taksonomi Bloom pada dimensi proses kognitif terbagi menjadi enam kerangka kategori, yaitu mengingat, memahami, mengaplikasikan, menganalisis, mengevaluasi, dan mencipta. Keterampilan berpikir diklasifikasikan menjadi dua tingkatan yaitu keterampilan berpikir tingkat rendah (Lower Order Thingking Skill ) yang terdiri atas mengingat (C1), memahami (C2), mengaplikasikan (C3) serta keterampilan berpikir tingkat tinggi (Higher Order Thingking Skill ) terdiri atas menganalisis (C4), mengevaluasi (C5), dan mencipta (C6) (Krathwohl \& Anderson, 2001).

HOTS (Higher Order Thinking Skill ) merupakan kemampuan berpikir pada tingkat lebih tinggi dari pada sekadar menghafal fakta dan menyampaikan kembali informasi yang diketahui peserta didik. Menurut Vui (Kurniati,2014:62) higher

Order thinking Skill akan terjadi ketika seseorang mengaitkan informasi baru dengan infromasi yang sudah tersimpan didalam ingatannya dan mengaitkannya atau menata ulang serta mengembangkan informasi tersebut untuk mencapai suatu tujuan atau menemukan suatu penyelesaian dari suatu keadaan yang sulit dipecahkan.

Melihat kenyataan saat ini, banyak peserta didik belum memiliki kemampuan berpikir tingkat tingi, masih pada kemampuan menghafal. Kemampuan berpikir tingkat tinggi (Higher Order Thinking Skill)sangat pentingditerapkan dalam berbagai aspek pengetahuan. Kurikulum 2013menghendaki peserta didik berpikir HOTS(Higher Order Thinking Skill). Para peserta didik dikembangkan untuk belajar berpikir tingkat tinggi. Guru tidak lagi memberitahu peserta didik, melainkan peserta didik harus mencaritahu. Mencaritahu artinya butuh proses berpikir cerdas dan kreatif. Berpikir cerdas dan kreatif berarti berpikir tingkat tinggi. Kemampuan berpikir tingkat tinggi yang diperkenalkan sejak dini dibangkus ekolah akan berdampak positif kelak kemudian hari. Seorang guru harus dapat membaca berbagai fenomena dan perkembangan yang update agar dapat mengembangkan, merencanakan, dan melaksanakan rangkaian pembelajaran secara 
optimal demi terciptanya proses pendidikan yang bermutu dan berkualitas. Peserta didik secara mandiri mampu membaca dan mengidentifikasi berbagai fenomena, tantangan, permasalahan, dan perkembangan yang ada sehingga dapat membawa dan menggiring peserta didik mengarah pada kemampuan berpikir tingkat tinggi.

Berdasarkan hasil supervisi akademik yang peneliti sekaligus sebagai kepala sekolah lakukan pada semester sebelumnya menunjukkan bahwa, keterampilan berpikir tingkat tinggi peserta didik masih kurang,hal ini dapat dilihat dari penggunaan indikator pada RPP, pelaksanaan pembelajaran hingga penilaian pembelajaran level kognitif belum sepenuhnya mengarah ke HOTS. Tingkat ketercapaian tujuan pembelajaran peserta didik harus dilakukan melalui penilaian. Salah satu teknik penilaian dapat dilakukan dengan cara memberikan soal-soal pada peserta didik. Sistem penilaian yang dilakukan masih mengutamakan tes tertulis pada pengukuran kemampuan mengingatdan memahami. Dalam taksonomi, kemampuan tersebut termasuk dalam keterampilan berpikir tingkat rendah/lower order thingking Skill (LOTS). Penerapan dan pengembangan keterampilan tingkat tinggi/higher order thinking Skill(HOTS) pada peserta didik sekolah dasar perlu ditingkatkan lagi.

Sekarang ini di sekolah dasar menggunakan Kurikulum 2013 yang di dalamnya menerapkanpendekatansaintifik (5M)yang meliputi mengamati, menanya, mengumpulkan informasi, menalar, dan mengomunikasikan mampu mengubah iklim pembelajaran menjadi lebih aktif, kolaboratif, dan partisipatif yang memungkinkan untuk penerapan pembelajaran yang mengarah pada kemampuan berpikir tingkat tinggi peserta didik. Penerapan beberapa model pembelajaran seperti pembelajaran berbasis proyek (project based learning), pembelajaran berbasis masalah (problem basedlearning), pembelajaran dengan (problem solving), menemukan (discovery/inquiry), menjadi peluang bagi guru untuk menerapkan kegiatan pembelajaran pada level HOTS (Higher Order Thinking Skill) (Astutik, 2017).

UPT SD Negeri 210 Lemahabang Kabupaten Luwu Utarayang merupakan sekolah peneliti sebagai kepala sekolah, sudah mengimplementasikan kurikulum 2013 dengan memfasilitasi pesertadidik yang mengarah pada kemampuan berpikir pesertadidik menuju level yang lebih tinggi melalui pembelajaran tematik.
Guru telah menyusun Rencana Pelaksanaan Pembelajaran (RPP) mengimplementasikan highe rorder thingking Skill(HOTS) dalam pembelajaran tematik, namun kenyataannya Rencana Pelaksanaan Pembelajaran (RPP) yang mereka susun belum seperti apa yang diharapkan sesuai dengan ketentuan dalam buku pegangan pembelajaran berorientasi pada keterampilan berfikir tingkat tinggi. Selanjutnya peneliti memilih guru kelas tinggi yaitu guru kelas , karenap eserta didik kelas akan mengikuti UASBN yang soal-soal umumnya telah berorientasi pada keterampilan berfikir tingkat tinggi, maka seharusnya guru kelas sudah memunyai kompetensi HOTS dalam mengimplementasikan dipembelajaran tematik diawali dari perencanaan pembelajaran yang berorientasi pada keterampilan berfikir tingkat tinggi pula. Penelitian mengenai keterampilan berpikir tingkat tinggi (HigherOrder Thingking Skill) dapat memberikan pengetahuan terutama bagi pendidik agar tidak hanya menerapkan model, metode, dan teknik pembelajaran yang hanya menanamkan kemampuan menghafal. Penelitian akan dilakukan pada aspek perencanaan pembelajaran, Hal ini dilakukan guna mengetahui implementasi higher order thingking Skill pada pembelajaran tematik yang sudah diterapkan oleh guru di sekolah. Pendidik diarahkan untuk mampumenerapkan pembelajaranyang mengarah pada keterampilan berpikir tingkat tinggi (HigherOrder Thingking Skill ) pada peserta didik yang dikehendaki pada Kurikulum 2013.

\section{METODE PENELITIAN}

Penelitian ini berbentuk Penelitian Tindakan Kelas menggunakan pendekatan kualitatif dengan metode deskriptif karena penelitian ini dimaksudkan untuk mendeskripsikan peristiwa peningkatan yang terjadi dari siklus ke siklus yang terjadi di lapangan secara alamiah. Hal ini sejalan dengan pendapat Nawawi (1985) yang menjelaskan bahwa Metode deskriptif merupakan prosedur pemecahan masalah yang diselidiki dengan menggambarkan/melukiskan keadaan subjek/objek penelitian pada saat sekarang berdasarkan fakta-fakta yang tampak atau sebagaimana adanya.

Arikunto (2006) menyatakan bahwa penelitian tindakan sekolah dilakukan dalam dua siklus, dalam setiap siklus terdiri dari empat tahapan yakni: tahap (1) perencanaan, (2) pelaksanaan tindakan, (3) observasi dan (4) 
evaluasi dan refleksi. Desain penelitian ini dapat dilihat dalam Gambar dibawah ini :

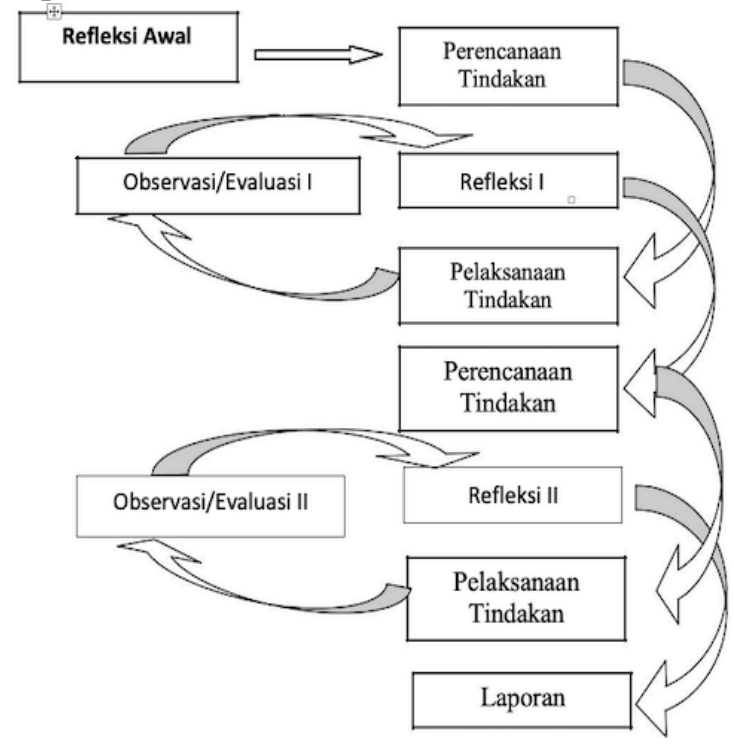

Gambar 1. Alur PTS (Diadaptasi dari Kemmis and Mc Taggart dalam Arikunto, 2006)

Subyek penelitian ini adalah guru kelas kelas UPT SD Negeri 210 Lemahabang Kabupaten Luwu Utarayang berjumlah 12 (dua belas) orang. Teknik pengumpulan data dalam penelitian ini adalah dokumen, observasi, dan wawancara.

\section{HASIL \& PEMBAHASAN}

Dari hasil supervisi pada tahun sebelumnya terhadap sepuluh orang guru,peneliti memperoleh informasi bahwa semua guru (dua belasorang) masih menerapkan carakonfesional mengajar dalam RPP yang disusunnya, umumnya guru menerapkanmodel pembelajaran konfensional yang sudah ada sejak dulu, kebanyakan guru tidak tahu dan tidak paham dalam menerapkanmodel pembelajaran yang lebih inovatif dan kreatif sesuai dengan tuntutan zaman abad 21 seperti pembelajaran berbasis proyek (project based learning), pembelajaran berbasismasalah(problem

basedlearning),pembelajarandengan pendekatanpenyelesaianmasalah(problem solving), menemukan atau penelitian(discovery/inquiry),menjadi peluangbagi guruuntuk menerapkan kegiatan pembelajaran padalevel HOTS(Higher Order Thinking Skill)(Astutik, 2017).sehingga dapat menarik minat peserta didik dalamperoses belajar.

Berdasarkan hasil observasi peneliti terhadapRPP yang disusun guru (khusus pada siklus pertama), diperolehinformasi/data bahwa masih ada guru yang masih menerapkanmodel pembelajaran konfensional dalam RPP yang disusunnya.

Dilihat dari segi kompetensi, terjadi peningkatanguru menyusun RPP yang berorientasi pada keterampilan berpikir tingkat tinggi (Higher Order Thingking Skill) darisiklus ke siklus. Hal itu dapat dilihat padapembahasan Hasil dari Siklus ke Siklus.

1. Siklus pertama

Siklus pertama terdiri dari empat tahap yakni: (1)perencanaan, pelaksanaan, (3) observasi, dan (4) refleksi seperti berikut ini.

1) Perencanaan (Planning)

a. Membuat format/instrumen penilaian kompetensi guru dalam menyusun RPP yang berorientasi pada keterampilan berpikir tingkat tinggi (Higher Order Thingking Skill),

b. Membuat format rekapitulasi hasil dari siklus 1 dan siklus 2

c. Membuat format rekapitulasi hasil dari siklus ke siklus

2) Pelaksanaan (Acting)

Hasil observasi pada siklus pertama yang dilaksanakan pada tanggal 11 s.d. 23 Februari 2019 , setiap hari Jumat pukul 13.00 s.d. 15.00 Wita, terhadap delapan orang guru. Semuanya menyusunRPP yang berorientasi pada keterampilan berpikir tingkat tinggi (Higher Order Thingking Skill) melaluiFocus Group Discussion (FGD). Dari hasil penyusunn

rerata keberhasilan kinerja adalah sebesar 68,08\%, dengan kriteria Cukup, belum mencapai indikator pencapaian hasil paling rendah $80 \%$, masih dilanjutkanpada siklus berikutnya, dan untuk mengetahui lebih jelas kompetensi guru dalammenyusun RPP yang berorientasi pada keterampilan berpikir tingkat tinggi (Higher Order Thingking Skill) melalui Focus Group Discussion (FGD), dapat dilihat pada kriteria hasil pengamatan padakompetensimasing-masinggurusiklus pertama ditunjukkan pada tabel berikut:

Tabel 1. Perbandingan Kriteria Hasil Pengamatan Kompetensi Guru dalam menyusun RPP Siklus pertama Siklus 1

\begin{tabular}{|c|l|c|c}
\hline \hline No. & \multicolumn{1}{|c|}{ Kreteria } & Jumlah & Prosentase \\
\hline 1 & A = Baik Sekali & 0 & 0 \\
\hline 2 & B = Baik & 3 & 25,00 \\
\hline 3 & C = Cukup & 7 & 58,33 \\
\hline
\end{tabular}




\begin{tabular}{|c|c|c|c|}
\hline 4 & $\mathrm{D}=$ Kurang & 2 & 16,67 \\
\hline 5 & $E=$ Sangat kurang & 0 & 0 \\
\hline & Jumlah & 12 & 100 \\
\hline \multicolumn{3}{|c|}{$\%$ Rerata Kinerja } & 68,08 \\
\hline
\end{tabular}

Perbandingan kriteria hasil pengamatan Kreatifitas Guru dalam menyusun RPP yang berorientasi pada keterampilan berpikir tingkat tinggi (Higher Order Thingking Skill) melalui Focus Group Discussion (FGD)pada siklus pertama ditunjukkan pada gambar berikut:

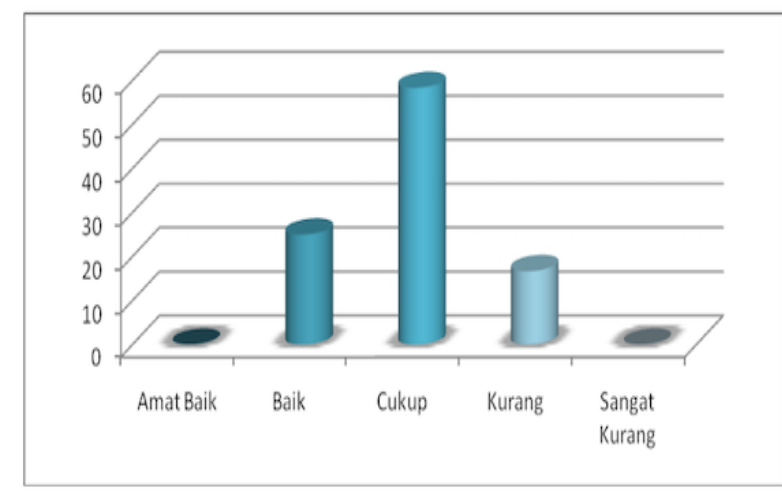

Gambar 2. Diagram Perbandingan Kriteria Hasil Pengamatan Kompetensi Guru dalam menyusun RPP yang berorientasi pada keterampilan berpikir tingkat tinggi (Higher Order Thingking Skill) melalui Focus Group Discussion (FGD)Siklus I

Selanjutnya dilihat dari hasil analisis kompetensi guru yang dilakukan pada siklus pertama aspek keberhasilan dari setiap aspek kompetensi belum sesuai/tercapai seperti rencana/keinginan peneliti. Hal itu dibuktikan dengan masih rendahnya prosentase dari setiap aspeknya dan keseluruhan aspek masih dibawah standar yang ditetapkan. Yaitu dimana nilai setiap aspek masih dibawah $80 \%$ ditunjukkan pada tabel berikut:

Tabel 2 Hasil Observasi Setiap Aspek Kompetensi Siklus I

\begin{tabular}{clc}
\hline \hline No. & \multicolumn{1}{c}{ Aspek } & Rerata Kinerja \\
\hline 1 & $\begin{array}{l}\text { Mempersiapkan } \\
\text { Pembelajaran }\end{array}$ & 71,83 \\
\hline 2 & $\begin{array}{l}\text { Memfasilitasi Kegiatan } \\
\text { Pembelajaran }\end{array}$ & 64,33 \\
\hline & Rerata Kinerja & 68,08 \\
\hline \hline
\end{tabular}

Hasil observasi pada siklus pertama dari 12 (dua belas) orang guru dari setiap aspek kompetensi, dapat dideskripsikan berikut ini :

a. Aspek Mempersiapkan Pembelajaran rerata keberhasilan kinerja adalah sebesar 71,83\%, dengan kriteria cukup. b. Aspek Memfasilitasi Kegiatan Pembelajaran, rerata keberhasilan kinerja adalah sebesar $64,33 \%$, dengan kriteria kurang.

Berdasarkan pembahasan di atas kompetensi gurudalam melakukan pembelajaran High Order Thinking Skill (HOTS) dengan bimbingan. pada siklus pertama nilai prosentase rata-rata ketercapaianaspek penilaian adalah $68,08 \%$ ( cukup). Untuk mengetahui lebih jelas hasil setiap aspek penilaian menyusunan RPP yang berorientasi pada keterampilan berpikir tingkat tinggi (Higher Order Thingking Skill) melalui Focus Group Discussion (FGD), dapat dilihat pada perbandingan hasil pengamatan pada masing-masing kompetensiguru siklus pertama di tunjukkan pada gambar berikut:

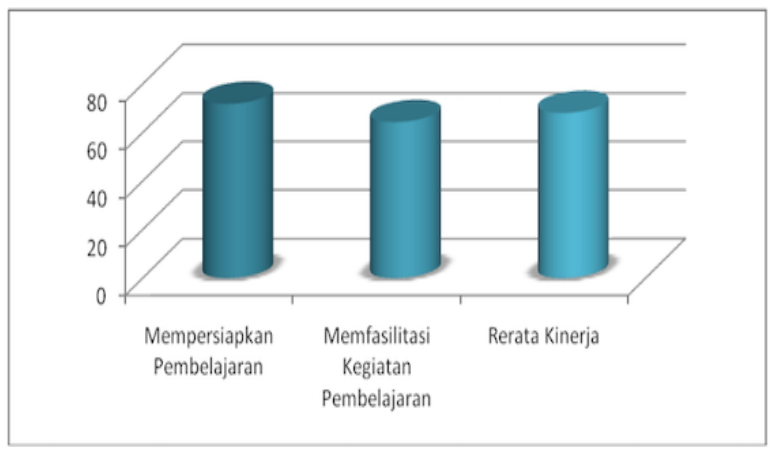

Gambar 3 Diagram Perbandingan Setiap Aspek

Hasil Pengamatan Kompetensi Guru dalam menyusun RPP yang berorientasi pada keterampilan berpikir tingkat tinggi (Higher Order Thingking Skill) melalui Focus Group Discussion (FGD) Siklus I

2. Siklus kedua (Kedua)

Siklus kedua juga terdiri dari empat tahap yakni: (1) perencanaan, (2) pelaksanaan, (3) observasi, dan (4) refleksi seperti berikut ini.

1) Perencanaan (Planning)

a. Membuat format/instrumen penilaian kompetensi guru dalam mengajar,

b. Membuat format rekapitulasi hasil siklus 2

c. Membuat format rekapitulasi hasil dari siklus ke siklus

2) Pelaksanaan (Acting)

Hasil observasi pada siklus kedua yang dilaksanakan pada tanggal 25 Februari s.d. 07 Maret 2019 , setiap hari Senin s.d Sabtu pukul 13.00 s.d. 15.00 Wita, terhadap 12 (dua belas) orang guru. 
Semuanya menyusun rencana pelaksanaan pembelajaran berorientasi pada keterampilan berpikir tingkat tinggi (Higher Order Thingking Skill) dalam pembelajaran tematik melalui Focus Group Discussion (FGD), dapat dikemukakan pada tabelsebagai berikut.

Tabel 3 Hasil Observasi Kompetensi Guru Dalam Menyusun Rencana Pelaksanaan Pembelajaran Berorientasi Pada Keterampilan Berpikir Tingkat Tinggi (Higher Order Thingking Skill ) Siklus II

\begin{tabular}{|c|c|c|c|c|}
\hline No & Nama & Kelas & $\begin{array}{l}\dot{\bar{a}} \\
\overline{\tilde{\omega}} \\
\dot{\Xi} \\
\dot{\Xi}\end{array}$ & $\%$ \\
\hline 1 & $\begin{array}{l}\text { ANDI MUSLINDA, } \\
\text { S.Pd.I. }\end{array}$ & VI a & 90 & 90.00 \\
\hline 2 & $\begin{array}{l}\text { KANATANG, } \\
\text { S.Pd.SD. }\end{array}$ & VI b & 88 & 88.00 \\
\hline 3 & SUHAEBA, S.Pd.SD. & VI c & 94 & 94.00 \\
\hline 4 & UMIATI AM, S.Pd.I. & $\mathrm{Va}$ & 85 & 85.00 \\
\hline 5 & SANTI, A.Ma. & $\mathrm{Vb}$ & 80 & 80.00 \\
\hline 6 & DARWAN, S.Pd.SD. & IV a & 87 & 87.00 \\
\hline 7 & ANITA, S.Pd.SD. & IV b & 83 & 83.00 \\
\hline 8 & $\begin{array}{l}\text { AGUNG HANAFI, } \\
\text { S.Pd. }\end{array}$ & III a & 76 & 76.00 \\
\hline 9 & WIWIK, S.Pd.SD. & III b & 75 & 75.00 \\
\hline 10 & IRMA ELVIANA & II a & 74 & 74.00 \\
\hline 11 & KIKI, A.Ma & $\mathrm{II} b$ & 86 & 86.00 \\
\hline 12 & $\begin{array}{l}\text { SAMRIANA B., } \\
\text { S.Pd.SD. }\end{array}$ & I a & 91 & 91.00 \\
\hline
\end{tabular}

Rerata Kinerja

Berdasarkan tabel di atas kompetensi guru dalam menyusun rencana pelaksanaan pembelajaran berorientasi pada keterampilan berpikir tingkat tinggi (Higher Order Thingking Skill ) dalam pembelajaran tematik melalui Focus Group Discussion (FGD),di UPT SD Negeri 210 Lemahabang kabupaten Luwu Utara. pada siklus keduarerata keberhasilan kinerja adalah sebesar 84,08\%, dengan kriteria Baik, telah mencapai indikator pencapaian hasil paling rendah $80 \%$, tidak perlulagi dilanjutkan pada siklus berikutnya, dan untuk mengetahui lebih jelas kompetensi guru dalam menyusun rencana pelaksanaan pembelajaran berorientasi pada keterampilan berpikir tingkat tinggi (Higher Order Thingking Skill ) dalam pembelajaran tematik melalui Focus Group Discussion (FGD), dapat dilihat pada kriteriahasil pengamatan pada kompetensi masing-masing gurusiklus kedua ditunjukkan pada tabel berikut:

Tabel 4 Perbandingan Kriteria Hasil Pengamatan Kompetensi Guru dalam Menyusun RPPBerorientasi Pada Keterampilan Berpikir Tingkat Tinggi (HOTS) Dalam Pembelajaran Tematik Melalui Focus Group Discussion (FGD)Siklus II

\begin{tabular}{|c|c|c|c|}
\hline No. & Kreteria & Jumlah & Prosentase \\
\hline 1 & $\mathrm{~A}=$ Baik Sekali & 2 & 16,67 \\
\hline 2 & $\mathrm{~B}=$ Baik & 8 & 66,67 \\
\hline 3 & $\mathrm{C}=$ Cukup & 2 & 16,67 \\
\hline 4 & $\mathrm{D}=$ Kurang & 0 & 0 \\
\hline 5 & $\begin{array}{l}\mathrm{E}=\text { Sangat } \\
\text { kurang }\end{array}$ & 0 & 0 \\
\hline & Jumlah & 12 & 100 \\
\hline \multicolumn{3}{|c|}{$\%$ Rerata Kinerja } & 84,08 \\
\hline
\end{tabular}

Perbandingan kriteria hasil pengamatan kreatifitas guru dalam menyusun rencana pelaksanaan pembelajaran berorientasi pada keterampilan berpikir tingkat tinggi (Higher Order Thingking Skill ) dalam pembelajaran tematik melalui Focus Group Discussion (FGD),pada siklus pertama ditunjukkan pada gambar berikut:

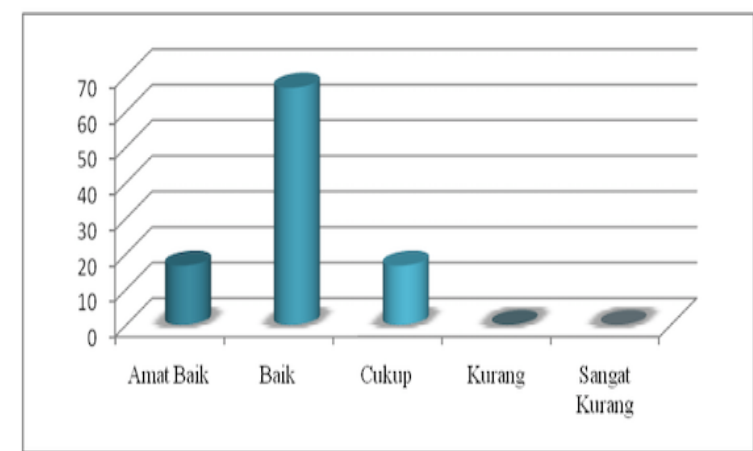

Gambar 4 Diagram Perbandingan Kriteria Hasil Pengamatan Kompetensi Guru Dalam Menyusun Rencana Pelaksanaan Pembelajaran Berorientasi Pada Keterampilan Berpikir Tingkat Tinggi (Higher Order Thingking Skill ) Dalam Pembelajaran Tematik Melalui Focus Group Discussion (FGD),Siklus II

Selanjutnya dilihat dari hasil analisis kompetensi guru yang dilakukan pada siklus kedua aspek keberhasilan dari setiap aspek kompetensi telah sesuai/tercapai seperti rencana/keinginan peneliti. Hal itu dibuktikan dengan meningkatnya prosentase dari setiap aspeknya dan keseluruhan aspek telah di atas standar yang ditetapkan, yaitu dimana nilai setiap aspek telah di atas $80 \%$ ditunjukkan pada tabel berikut: 
Tabel 5 Hasil Observasi Setiap Aspek Kompetensi Siklus II

\begin{tabular}{clc}
\hline \hline No. & \multicolumn{1}{c}{ Aspek } & Rerata Kinerja \\
1 & $\begin{array}{l}\text { Mempersiapkan } \\
\text { Pembelajaran }\end{array}$ & 83,50 \\
2 & $\begin{array}{l}\text { Memfasilitasi Kegiatan } \\
\text { Pembelajaran }\end{array}$ & 84,67 \\
& Rerata Kinerja & 84,08 \\
\hline \hline
\end{tabular}

Hasil observasi pada siklus pertama ni dari 12 (dua belas) orang guru dari setiap aspek kompetensi, dapat dideskripsikan berikut ini :

a. Aspek Mempersiapkan Pembelajaran, rerata keberhasilan kinerja adalah sebesar $83,50 \%$, dengan kriteria Baik.

b. Aspek Memfasilitasi Kegiatan Pembelajaran, rerata keberhasilan kinerja adalah sebesar $84,67 \%$, dengan kriteria Baik.

Berdasarkan pembahasan di atas kompetensi gurudalam menyusun rencana pelaksanaan pembelajaran berorientasi pada keterampilan berpikir tingkat tinggi (Higher Order Thingking Skill ) dalam pembelajaran tematik melalui Focus Group Discussion (FGD),pada siklus kedua nilai prosentase rata-rata ketercapaian aspek penilaian adalah $84,08 \%$ dengan kriteria Baik. Untuk mengetahui lebih jelas hasil setiap aspekpenilaian dalam menyusun rencana pelaksanaan pembelajaran berorientasi pada keterampilan berpikir tingkat tinggi (Higher Order Thingking Skill) dalam pembelajaran tematik melalui Focus Group Discussion (FGD), dapat dilihat pada perbandingan hasil pengamatan pada masing-masing kompetensiguru siklus pertama di tunjukkan pada gambar berikut:

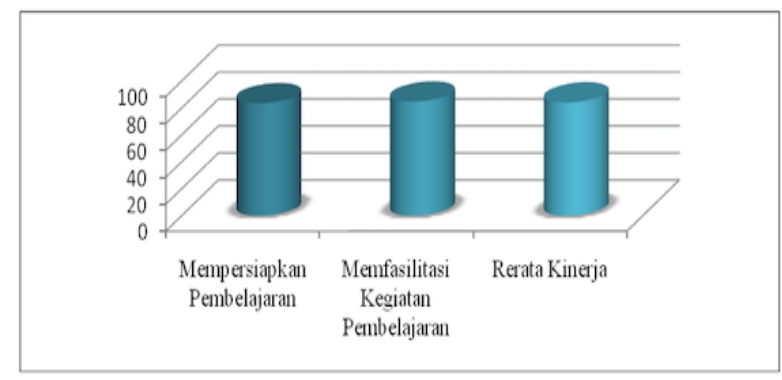

Gambar 5 Diagram Perbandingan Setiap

Aspek Hasil Pengamatan Kompetensi Guru dalam Menyusun RPP Pada,Siklus II

\section{Pembahasan}

Penelitian Tindakan Sekolah dilaksanakan di sekolah binaanUPT SD Negeri 210 Lemahabang kabupaten Luwu Utara yang merupakan sekolah yang penelitipimpin terdiri atas 12 (dua belas) guru, dan dilaksanakan dalam dua siklus. Kedelapan guru tersebut menunjukkan sikap yang baik dan termotivasi untuk meningkatkan kompetensi dalam menyusun rencana pelaksanaan pembelajaran berorientasi pada keterampilan berpikir tingkat tinggi (Higher Order Thingking Skill ) dalam pembelajaran tematik melalui Focus Group Discussion (FGD). Hal ini peneliti ketahui dari hasil pengamatan pada saat melakukan diskusimenyusun rencana pelaksanaan pembelajaran berorientasi pada keterampilan berpikir tingkat tinggi (Higher Order Thingking Skill ) dalam pembelajaran tematik melalui Focus Group Discussion (FGD),yang ditunjukkan dengan adanya peningkatan, yaitu pada siklus pertama kompetensi guru dalam menyusun rencana pelaksanaan pembelajaran berorientasi pada keterampilan berpikir tingkat tinggi (Higher Order Thingking Skill ) dalam pembelajaran tematik melalui Focus Group Discussion (FGD),yaitu rerata keberhasilan kinerja adalah sebesar 68,08\%, dengan kriteria Cukup. Sedang pada siklus kedua kompetensi guru dalam menyusun rencana pelaksanaan pembelajaran berorientasi pada keterampilan berpikir tingkat tinggi (Higher Order Thingking Skill) dalam pembelajaran tematik melalui Focus Group Discussion (FGD),denganrerata keberhasilan kinerja adalah sebesar $84,08 \%$, dengan kriteria Baik.Prosentase rata-rata ketercapaiankompetensi guru dalam menyusun rencana pelaksanaan pembelajaran berorientasi pada keterampilan berpikir tingkat tinggi (Higher Order Thingking Skill ) dalam pembelajaran tematik melalui Focus Group Discussion (FGD)meningkat sebesar 16,00\%dari siklus pertama kesiklus kedua.

\section{KESIMPULAN \& SARAN}

Berdasarkan hasil Penelitian Tinadakan Sekolah (PTS)dapat disimpulkan sebagai berikut.

1. Focus Group Discussion (FGD)dapat meningkatkan kompetensiguru dalam menyusun rencana pelaksanaan pembelajaran berorientasi pada keterampilan berpikir tingkat tinggi (Higher Order Thingking Skill ) dalam pembelajaran tematik. Guru menunjukkan keseriusan dalam berdiskusidan melakukan menyusun rencana pelaksanaan pembelajaran berorientasi pada keterampilan berpikir tingkat tinggi (Higher Order Thingking Skill ) dalam pembelajaran tematikdengan bimbingan dari peneliti. Informasi ini 
peneliti peroleh dari hasil pengamatan pada saatFocus Group Discussion (FGD) menyusun rencana pelaksanaan pembelajaran berorientasi pada keterampilan berpikir tingkat tinggi (Higher Order Thingking Skill ) dalam pembelajaran tematik.

2. Focus Group Discussion (FGD)dapat meningkatkan kompetensi guru dalam menyusun rencana pelaksanaan pembelajaran berorientasi pada keterampilan berpikir tingkat tinggi (Higher Order Thingking Skill ) dalam pembelajaran tematik.Hal itu dapat dibuktikan dari hasil observasi/pengamatan yang memperlihatkan bahwa terjadi peningkatan kompetensi guru dari siklus ke siklus, yaitu terjadi peningkatan sebesar $16,00 \%$ untuk kompetensi guru dalam menyusun rencana pelaksanaan pembelajaran berorientasi pada keterampilan berpikir tingkat tinggi (Higher Order Thingking Skill ) dalam pembelajaran tematik dari siklus pertama kesiklus kedua.

\section{DAFTAR PUSTAKA}

Daradjat, Zakiyah. 1980. Kepribadian Guru. Jakarta: Bulan Bintang.

Depdiknas. 2003. UU RI No. 20 Tahun 2003 tentang Sistem Pendidikan Nasional. Jakarta: Depdiknas.

2005. UU RI No. 14 Tahun 2005 tentang Guru dan Dosen. Jakarta: Depdiknas.

2005. Standar

Nasional

Pendidikan. Jakarta: Depdiknas.

2007. Permendiknas RI No. 41 Tahun $2007 a$ tentang Standar Proses. Jakarta: Depdiknas. 2008. Alat Penilaian Kemampuan G uru. Jakarta: Depdiknas.

2009. Petunjuk Teknis Pembuatan Laporan Penelitian Tindakan Sekolah Sebagai Karya Tulis Ilmiah Dalam Kegiatan Pengembangan Profesi Pengawas Sekolah. Jakarta.
Fatihah, RM . 2008. Pengertian konseling (Http://eko13.wordpress.co $\mathrm{m}$, diakses 10 Juli 2016 ).

Imron, Ali. 2000. Pembinaan Guru Di Indonesia. Malang: Pustaka Jaya.

Kemendiknas. 2010. Penelitian Tindakan Sekolah. Jakarta.

2010. Supervisi Akademik. Jakarta.

Kemendikbud. 2018. Buku Pegangan Pembelajaran Berorientasi pada Keterampilan Berpikir Tingkat Tinggi.Direktorat Jenderal Guru Dan Tenaga Kependidikan Kementerian Pendidikan Dan Kebudayaan Jakarta.

Kumaidi. 2008. Sistem

Sertifikasi (http://massofa.wordpress. com diakses 10 Juli 2016 ).

Nawawi, Hadari. 1985. Metode Penelitian Bidang Sosial. Yogyakarta: Gadjah Mada University Press.

Nurhadi. 2004. Kurikulum 2004. Jakarta: PT Gramedia Widiasarana Indonesia.

Pidarta, Made . 1992. Pemikiran Tentang Supervisi Pendidikan. Jakarta: Bumi Aksara.

Sudjana, Nana. 2009. Standar Kompetensi Pengawas Dimensi dan Indikator. Jakarta : Binamitra Publishing.

Suharjono. 2003. Menyusun Usulan Penelitian. Jakarta: Makalah Disajikan pada Kegiatan Pelatihan Tehnis Tenaga Fungsional Pengawas.

Suharsimi Arikunto,2006. Prosedur Penelitian Suatu Pendekatan Praktek. Jakart: PT.Rineka Cipta.

Suharjono. 2003. Menyusun Usulan Penelitian. Jakarta: Makalah Disajikan pada Kegiatan Pelatihan Tehnis Tenaga Fungsional Pengawas.

Suparlan. 2005. Menjadi Guru Efektif. Yogyakarta: Hikayat Publishing. 2006. Guru Sebagai Profesi. Yogyakarta: Hikayat Publishing.

Tim Redaksi Kamus Besar Bahasa Indonesia. Edisi kedua. 